\title{
Norois
}

Environnement, aménagement, société

$221 \mid 2011$

Innovations et agricultures urbaines durables

\section{Socio-territorial changes in peri-urban food production spaces in Central Mexico}

Héctor Ávila-Sánchez

\section{(2) OpenEdition}

1 Journals

Electronic version

URL: https://journals.openedition.org/norois/3738

DOI: $10.4000 /$ norois.3738

ISBN: 978-2-7535-1838-4

ISSN: $1760-8546$

Publisher

Presses universitaires de Rennes

Printed version

Date of publication: 30 December 2011

Number of pages: $39-51$

ISBN: 978-2-7535-1786-8

ISSN: 0029-182X

Electronic reference

Héctor Ávila-Sánchez, "Socio-territorial changes in peri-urban food production spaces in Central

Mexico", Norois [Online], 221 | 2011, Online since 30 December 2013, connection on 13 January 2022. URL: http://journals.openedition.org/norois/3738 ; DOI: https://doi.org/10.4000/norois.3738

\section{(c) Tous droits réservés}




\title{
SOCIO-TERRITORIAL CHANGES
}

\section{in peri-urban food production spaces in Central Mexico}

\author{
HÉCTOR ÁvILA-SÁNCHEZ \\ Programa de Estudios Regionales \\ (Universidad Nacional Autónoma de México), \\ Centro Regional de Investigaciones Multidisciplinarias \\ Av. Universidad s/n Circuito 2, Chamilpa - 62210 Cuernavaca, Morelos, Mexique \\ ahector@servidor.unam.mx
}

\begin{abstract}
Agricultural practices are widespread in the periurban zones of developing countries. For periurban poor population, agriculture represents a complement to family income and an alternative for food supplies. For these peoples, the role of UPA (Urban and Periurban Agriculture) is very important. In Latin America, operation of periurban spaces has differentiated functions and roles: most of their inhabitants face conditions of marginalization or at best, subsist through the food self-production. Periurban poors are facing a double situation: the degradation of their activity and the transformation of their peasant condition; at the time, a conflict by the dispute for the space with other social groups, with different interests and meanings. In this paper we discuss about diverse manifestations of territorial restructuration in a global context, specifically in periurban areas of metropolitan system of Central Mexico. Above all, its interest lies in an analysis of these transformations within the context of the old rural spaces, those which have been affected by the advance of urbanization. The development of periurban agriculture in some cities of Central Mexico has established important patterns of territory transformation, either in changes of use of land or in the structure of production, or in social and cultural changes. Periurban agriculture is one of the several activities in this territory, that remains with another non-farming activities, mainly manufactures and tertiary, that are having an quick diffusion.
\end{abstract}

KEYWORDS : territorial changes - conflict - marginalization - periurbanization - urban and periurban agriculture

\section{RÉSUMÉ}

Changements socio-territoriaux dans les espaces périurbains de la production alimentaire au Centre du Mexique

Le rôle de l'UPA (Agriculture Urbaine et Périurbaine) est très important dans les zones périurbaines des pays en développement, dont en Amérique latine. Pour la population pauvre de ces zones, souvent confrontée à des conditions de marginalisation, leur exploitation par l'agriculture est un complément au revenu familial et une alternative pour l'approvisionnement alimentaire. Or, cette population doit faire face à une double situation: d'une part, la dégradation de son activité et la transformation de la condition paysanne en particulier dans les espaces ruraux anciens, touchés par l'avancée de l'urbanisation; d'autre part, l'affirmation de conflits pour l'utilisation de l'espace avec d'autres groupes sociaux, avec des intérêts et des significations différents. En somme, dans certaines villes du centre 
du Mexique, l'affirmation de l'agriculture périurbaine a conduit à une forte transformation $d u$ territoire, soit dans les changements d'utilisation des terres ou dans la structure de la production, soit des changements sociaux et culturels.

MOTS CLÉS : changements territoriaux - conflit-marginalisation-agriculture urbaine et périurbaine.

In the central region of Mexico, around the central metropolitan nucleus - the agglomeration of Mexico Valley - we recognize the dilated periurban space denominated the regional crown of Mexico City (as this is at its centre). We are talking about a dense patchwork of urban networks where most of the region's cities converge (metropolitan areas of Mexico, Toluca, Cuernavaca, Puebla, Pachuca, Querétaro, and other localities with more than 15 thousand inhabitants). This territorial scheme includes the development of rural industrialization districts (mainly manufactures and tertiary that having a quick diffusion). However, the growth experienced by Mexico City and its periphery has taken place mainly on agricultural lands, $60 \%$ of which were at the time under the regimen of collective property, in ejidos ${ }^{1}$ and/or agricultural properties. The main features of agricultural practice on metropolitan peripheries of Mexico City Regional Crown are:

1. UPA is a marginal occupation, practiced by poor agricultural producers (subsistence reasons). But there are also some farmers who export and use high-tech;

2. There is a permanent loss of agricultural lands due to urban expansion, up to $40 \%$ of rural areas that surround cities, in the span of the last 20 years;

3. Urban employment is increasing in periurban spaces;

4. A high percentage of land renting, mainly of social property (ejidos);

5. Deficit in the regeneration of youth labor in periurban areas;

6. Persistence of UPA as a cultural practice;

That way, periurban poor people are facing a complex situation : the degradation of their activity and the transformation of their peasant condition; at the time, there is a conflict for the space with other social groups, with different interests and meanings. This is one face of the New Rurality: the unequal access and use of urban-rural peripheral spaces, and consequently, redefinition and marginality increasing.

The purpose of this paper is also to present diverse manifestations of the restructuring of these territories in a global context by the food production. Above all, its interest lies in an analysis of these transformations within the context of the old rural spaces, those which have been affected by the advance of urbanization.

This research was conducted between 2003 and 2006 in five metropolitan areas of Central Mexico (Cuernavaca, Puebla, Tlaxcala, Toluca and Cuautla) with analysis of statistical information (economically active population in periurban areas, percentage of land under agricultural use; labor mobility, migration of the workforce). We also interviewed leaders of agricultural unions in metropolitan peripheries, in order to find out the precise causes of changes in land use and land ownership.

The paper comprises three parts: the first presenting the main theoretical developments on the transformation of territories within the context of globalization; also provides some ideas about the urbanization occurring on the periphery of the Mexican cities; finally, there are some thoughts about the practice of agricultural activities in the cities, in essence, the formation of the Urban and Periurban Agriculture (UPA). The second part deals with specific territorial changes (peri-

1. Collective property of land. Legal figure created for the land distribution at the end of Mexican revolution (1928) and modified in 1992 in the context of "modernization of Mexican agriculture". The main action was that the peasants, who work the land of social property, could ask for the private property. 
urbanization) that have occurred in the metropolis of Central Mexico. The third part presents the characteristics of the process of urban and periurban agriculture in major cities of Central Mexico and provides some data and testimonies to reinforce the ideas. At the conclusion, it is pointed out some conclusions and/or proposals.

\section{The transformation of rural spaces}

The organization and restructuring of regions within the globalization process and the debate and/or paradigm on the reestablishment of industrial districts in the post-Fordist model of flexible production - "winners" or "losers" (Benko and Lipietz, 1994, 2000), has been critically revised and redefined over the end of 90's. For others positions in this debate, the notion of economic space as a category of analysis is reinforced, especially under the Spatial Economic Theory Approach. The central idea established here is the validity of the centre/periphery approach. So-called geographical economics is referred to in terms of "the localization of production in space" (Krugman, 1996). Other points of view recognize the territory as an expression of social relations in space. It is identified as a social construction in a spatial dimension, given meaning and life by a social group (Piolle, 1998, Di Meo, 1998). For example, in Latin American agrarian societies, despite the productive and social restructuring processes imposed by economic liberalization, the relationship these social groups have with their territorial environment continues to be very complex, with cultural processes still playing a central role.

The changes in the economy and society from second half of $20^{\text {th }}$ century, have transformed the essence of rural spaces. Aspects such as productive restructuring, rurbanization or periurbanization, rural environmental questions, agricultural modernization, rural tourism, periurban agriculture and female agricultural work, constitute a fundamental core in researching rural themes. Nowadays, the approach or idea of the New Rurality has permeated the analysis of rural spaces, in the different disciplines which are concerned with studying them.

Within the new centrality caused by globalization in local territories, rural spaces are made increasingly dependent on cities, but they continue to exist in new forms and with diverse operation strategies, adapting to new circumstances, whether in terms of production or of social and cultural aspects; in periurban territories, hybrid forms arise containing elements from both urban and rural settings.

A recent outcome of metropolitan expansion can be seen in the development of periurban zones. Even if urban growth rates have been modified over the last few decades, cities still keep on expanding. Latin American capitals continue to exert a substantial influence, and they establish norms in terms of the use and appropriation of urban-rural spaces in contact. Spaces which until recently maintained an important agricultural vocation, have now adapted to the cities' functions and requirements

Urbanization is one of main phenomena in the contemporary society. In some countries, urbanization has been closely associated with economic growth and eventually poverty reduction. But in Latin American countries it is not necessarily happening. In those countries, operation of periurban spaces has differentiated functions and roles: most of their inhabitants face conditions of marginalization or at best, subsist through the food self-production. The urban poor population faces difficulties in acquiring sufficient and healthy food from traditional rural agriculture. Agricultural practices are widespread in the periurban zones of developing countries. For periurban poor population, agriculture represents a complement to family income and an alternative for food supplies. For these peoples, the role of UPA (Urban and Periurban Agriculture) is very important. The urban poor population faces difficulties in acquiring sufficient and healthy food from traditional rural agriculture. Governmental policies either neglect or discourage the informal food systems on which the poor depend.

A policy for territorial intervention should locate the urban and periurban agriculture in the context of pluriactivity (with tertiary activities, productive, educational, and recreational or eco- 
tourism, as well as environmental protection) that minimize the negative impact of urbanization and promote the consumption of urban agricultural products. It is therefore necessary that this activity, which differs from traditional agriculture, should be included in territorial public policies; its practice should be promoted as an alternative to face poverty and as a contribution to community development.

\section{Urbanization and Territorial Reorganization in Mexico}

Nowadays, territorial transformations, which have occurred as a consequence of the uncontrolled expansion of urban zones in Mexico, are evident; both large and medium-sized cities grew uncontrollably in the seventies. Although the tendency began to be reverted towards the eighties, progress did not come to a complete stop. Enormous expanses of agricultural land were incorporated into the hierarchy and organization of big cities. For example, in the east of Mexico City, one of the biggest conurbations in the country was set up. New urban sub-centres were consolidated and others of lesser standing experienced territorial transformations displaying a transition between rurality and urbanity, with no clear tendency towards either one.

Since the eighties, a territorial reorganization has been witnessed in Mexico, characterized by the emergence of a stratum of medium and small-sized towns around the principal metropolises: Mexico City, Guadalajara and Monterrey (fig. 1). This is the result of a redefinition of the international division of labour and the subsequent adjustments in the previous economic model; this process could modify the ambits of rurality (the social and productive polarization of agricultural producers), at the same time it would affect socio-spatial restructuring and accentuate a territorial concentrated structure.

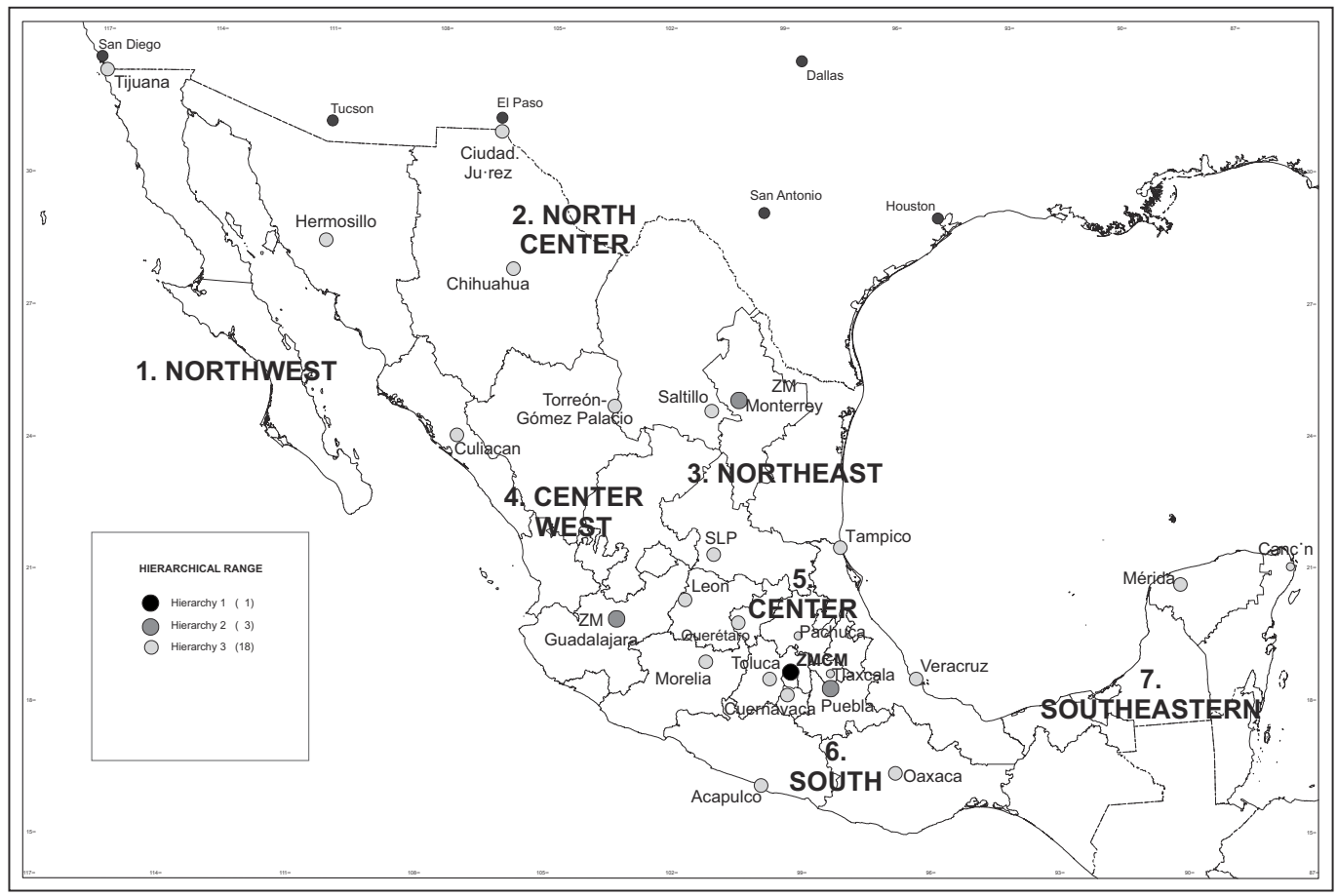

Figure 1: National urban system and regions of Mexico (INEGI [2006]) Système national urbaine et les régions du Mexique 
After the high urbanization rates of the seventies, the eighties were fundamental in the formation of the urban system in Mexico; factors such as the acute economic crisis, the process of greater economic opening and the accompanying structural changes necessary for operational capacity, modified the pattern of population distribution in the territory. In this way, since the mid-eighties, Mexico has experienced a gradual incorporation into the economic globalization processes, whose maximum expression up until now can be seen in the North American Free Trade Agreement in 1994. In principle, this is a reflection of economic tendencies towards globalizing markets and transformations in Mexican economic geography.

In the central region of Mexico, around the central metropolitan nucleus - the agglomeration of Mexico Valley - the dilated periurban space is in formation. We are talking about a dense patchwork of urban networks where most of the region's cities converge (the metropolitan areas of Mexico City, Toluca, Cuernavaca, Cuautla, Puebla, Pachuca and other localities with more than 15 thousand inhabitants; (figs. 2 and 3). This territorial scheme includes the development of rural industrialization districts (Delgado, 1999).

Furthermore, Aguilar (2006) proposed the approach of urban sprawl (dispersión urbana), to explain the processes and timing under which the peripheral areas of large cities have rapidly transformed, in comparison with other areas of the city (the central areas are losing population). Huge constructions transform completely peripheral areas due to its magnitude: transport infrastructure (roads, airports), vast housing developments (formal and informal), the emergence of industrial sites and corporate business management impact and change the use of large portions of agricultural land and its productive pattern.

The growth experienced by Mexico City has taken place mainly on agricultural lands, 60\% of which were at the time under the regimen of collective property, in ejidos and/or agricultural properties. In the fifties, substantial expanses of ejidal or communal lands were incorporated into urban zones, generally in the form of expropriations; lands which were originally destined to agricultural uses became susceptible to urbanization, even when the changes were carried out by agricultural authorities. Towards the end of the seventies, deprived urban areas began to spread onto communal and ejidal lands in immense proportions. The growing migratory pressure caused illegal sales of social property. In this way, deprivation and marginality are two phenomena which have accompanied urban expansion during the second half of the twentieth century.

Other rural spaces bordering Mexico City have suffered the onslaught of urbanization and have been transformed. Some examples are Chalco Valley and the south of the Mexico City Metropolitan Zone (Xochimilco, Tláhuac and Milpa Alta). If these spaces still maintain a rural feel, the urbanization drive is slowly changing the image and functions of these lands, with some functions that could be identified with both urban and rural settings. Currently, the agricultural plots are being abandoned, as contaminated water in Xochimilco Lake has reduced the productive capacity of the traditional crops, under the system of chinampas (man-made islands). Watering these crops with sewage water has caused a process of biological contamination and the salinization of the soil. In 1930, Xochimilco was situated outside of Mexico City and had 73 hectares of urban space; this has increased to more of 2,500 hectares in 2000, and is now totally swallowed up by the urban stain of Mexico City. The lake, which in the begginings of $20^{\text {th }}$ century had an extension of $350 \mathrm{~km}^{2}$, in 2007, had reduced their surface to $170 \mathrm{~km}^{2}$.

In 1992, a constitutional reform to article 27 took place. The possibility of privatizing ejidos was established, so ejidatarios are now free to do as they like with their property. In an urban context, the Agrarian Law anticipated that the ejidal lands situated in the growth area of a population centre should abide by the regulations and laws on human settlements: the Agrarian Law no longer restricts developers and beneficiaries of expropriations of ejidal and common land, who can now carry out this action personally; in this way, agricultural expropriations, previously considered as social property, can now become incorporated into the land market where they are generally used for housing. 


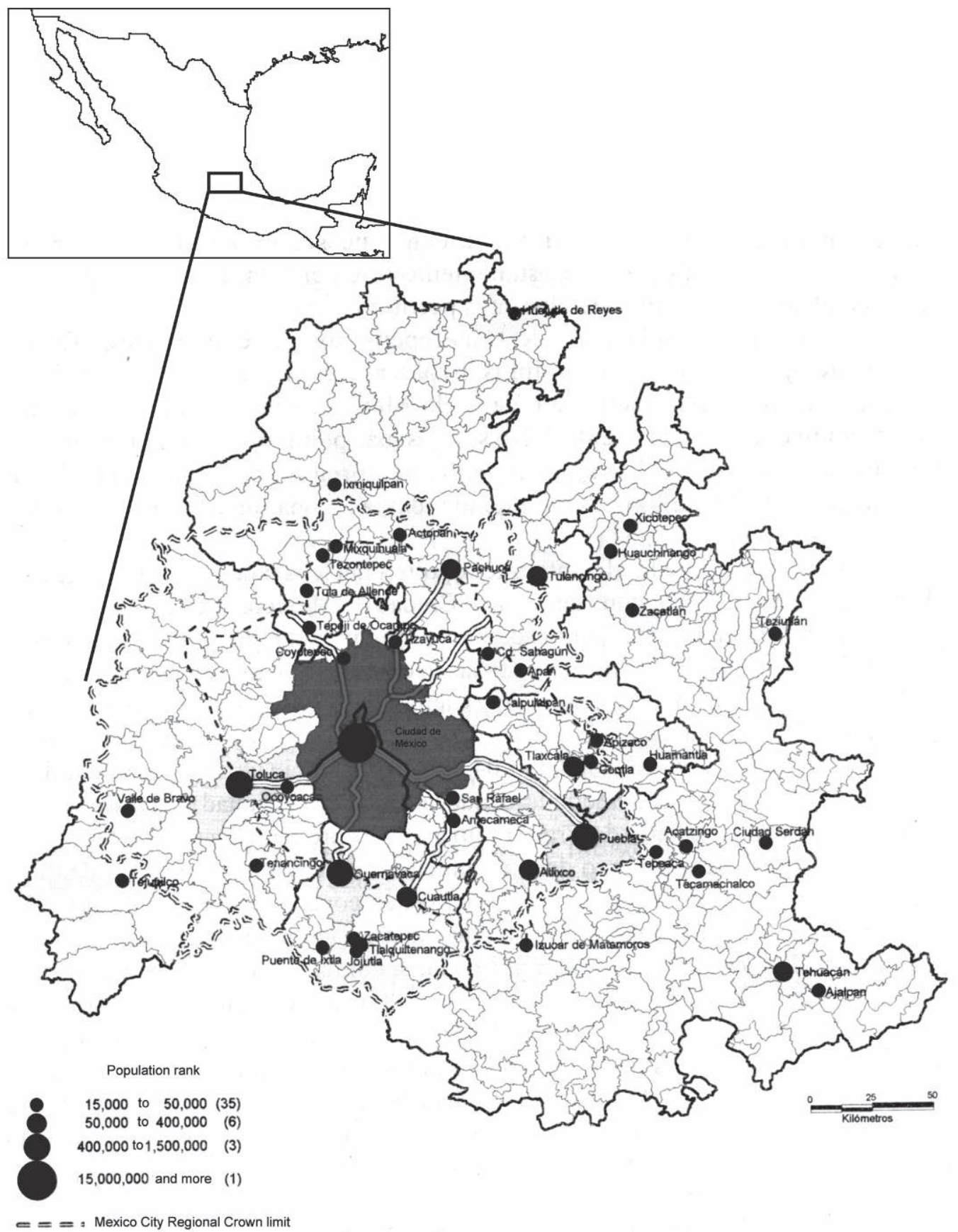

Figure 2: Cities Subsystem in Central Mexico (Delgado [1999])

Sous-système de villes du centre du Mexique 


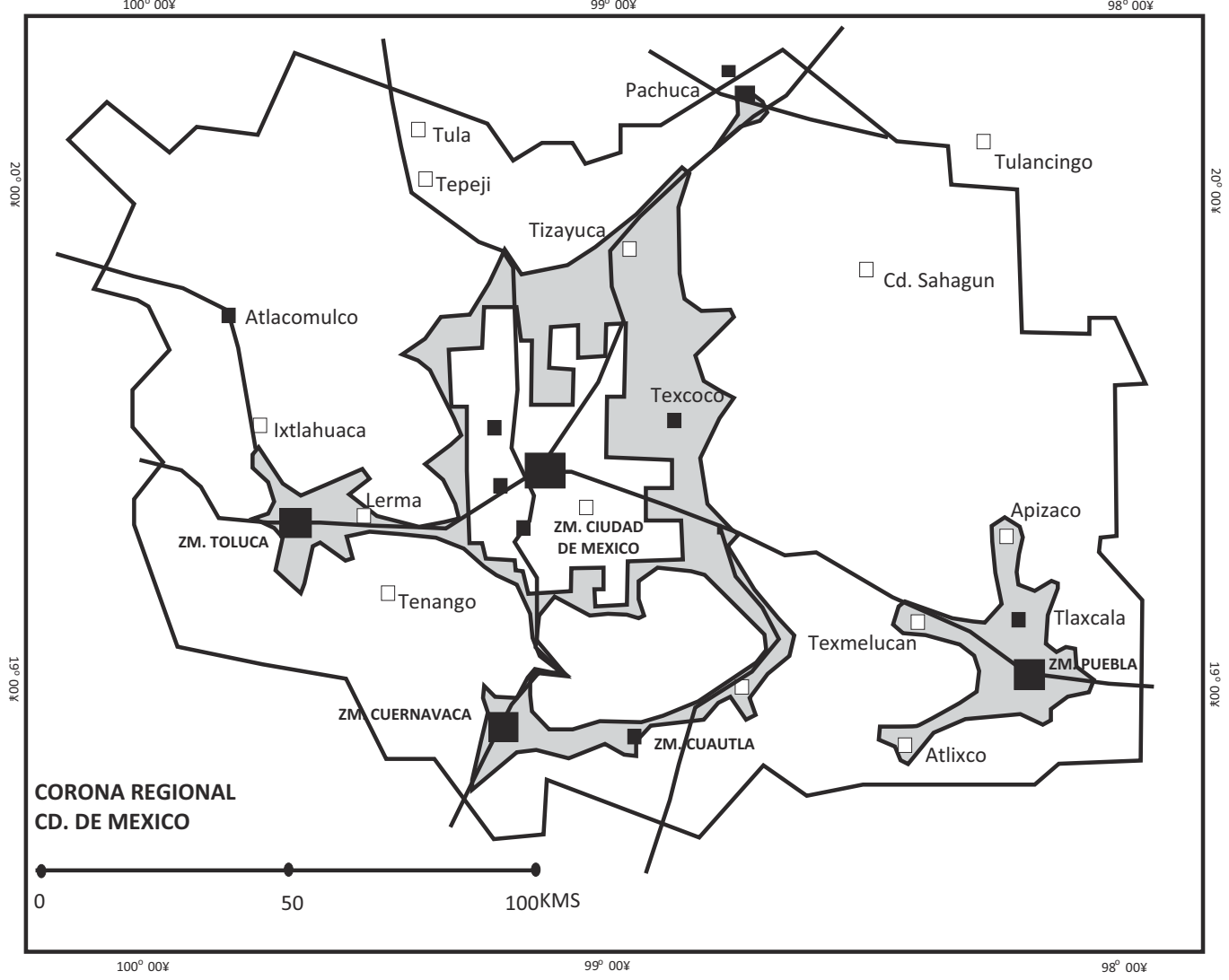

Figure 3 : Regional Crown of Mexico City (Delgado, Larralde and Anzaldo [1999]) Couronne Régionale de Mexico

Regarding the change of land tenure, social property was held by the program Procede. In 90\% of the cases, the opinions of ejido leaders favored the change, because Procede assures the land ownership ${ }^{2}$.

The persistence of agricultural activities, as an expression of the New Rurality, appears to be the clearest indicator of this type of relationship between cities and their immediate rural surroundings. Mexican urban economies display a high demand for agricultural products as well as for labor and land, the latter being for either productive or urban (housing or speculative) purposes. Since the decade of nineties, agricultural practices in several Mexican cities have reformulated the different variables which affect economic growth (particularly employment and productive activities), the maintenance of sustainable development policies and the life and cultural practices of local communities (Torres-Lima, 2000).

2. Procede, Certification Program of Ejido Rights and urban sites; its implementation caused conflicting opinions, for example, in the ejidos of Puebla periphery, the application of Procede was "a good program, because the parcel certificates are better (land property titles), in comparison to the agrarian certificates, which did not specify the ownership or usufruct. In addition, with the parcel certificates you can switch to full ownership, to internal land division" (leader of ejido San Juan Tlautla, Puebla (Pérez-Avilés. interview, 2003). The same situation happens on the periphery of Cuernavaca, where most of the 65 suburbs of the metropolitan area under investigation, considered to Procede as an advantage, "if the city keep growing, as is inevitably, when it runs out of agricultural lands (which will be the case) we have the right papers to sell at a better price" (leader of ejido Jiutepec, Morelos, interview by Ávila-Sánchez, 2004). 
In Mexico, various research projects have already been drawn up, especially regarding the appearance of this phenomenon in the periphery of Mexico City (Ibid. 2000). In the same manner, given the pattern of national urban growth, periurban agricultural practices have spread to many medium-sized cities in Central Mexico, such as Cuernavaca and Cuautla (Avila-Sánchez, 1997), Querétaro (Ramírez, 2000) or Texcoco (Aguilar and Escalona, 2000), amongst others, with important territorial and productive implications.

\section{Urban and Periurban agriculture (UPA) in the territorial transformations of Central Mexico}

Urban and periurban agriculture, as a systematic practice in the public policies of rural development, has acquired a paper of relative importance in some Latin American countries like Cuba, Argentina, Peru, Ecuador, among others. In Mexico, its practice has an ample tradition in places away from the city, but with the advance of the urbanization has been absorbed and that they have maintained his activities farming; this situation persists in two ways: by peasant tradition in the cities and peripherals, or as a survival strategy and contribution of resources to the family economy.

In Mexico, the territorial transformations have happened as a result of the uncontrolled expansion of the urban zones; the big cities were growing without control in the seventies; although the tendency began to revert towards the eighties, did not let progress. Extensive agricultural lands were incorporated in the hierarchy and dynamics of the big cities. Linked processes like the economic concentration, agricultural crises, the growth of the population and the migration towards the urban centers, the increase and null access to the urban ground, the marginality and poverty among others, explain the existence and development of the periurban phenomenon in several big cities of Mexico (Avila-Sánchez, 2001).

In the periphery of the Mexican cities and metropolis, the towns, ejidos and agrarian communities that have been absorbed by the expansion of the urban spot, practice farming and forest activities that adapt to different circumstances from the traditional agriculture of the countryside (Canabal, 2000). New forms about the use of the natural resources as far as the relations of land property are pronounced, where the pernicious effects of new agrarian dispositions, related to processes of accelerated urbanization are conjugated, in reference to a major regional context of greater amplitude. As J. Delgado (2003) had suggested, towards the beginning of the nineties it was possible to identify forms of urban and periurban agricultural exploitations in the main metropolitan agglomerations that integrate to the Mexico City Regional Crown (fig. 3). It has approximately registered 14000 units of rural production, located mainly in the periphery of the urban metropolitan conglomerates of Puebla, Tlaxcala, Cuernavaca, Cuautla, Pachuca, Toluca and Querétaro (Ibid., 2003).

Since the year 2000, several studies about territorial transformations and mutations of the scopes of the agricultural production have been developed, over Mexico's megalopoles (periurban zones and urban conglomerates surrounding the metropolitan zone of Mexico City).

For example in the metropolitan zone of Puebla (southeast of Mexico City), the fourth biggest city in the Mexican urban hierarchy, important territorial transformations have taken place. The construction of great commercial and housing developments in a zone of agrarian tradition (Angelópolis project), as well as the gradual transformation of the crops pattern on ejidal lands in the urban continumm, have modified the role and functions of the peripheral rural spaces (PérezAvilés and Silva, 2003). Nevertheless, its evolution fortified the regional concentration and the proliferation of the urban way of life in the rural peripheral surroundings. The regional strategy favored the installation of industries outside the limits of the urban conglomerate (industrial corridors) in expropriated ejidal lands. It promoted the urban infrastructure (construction of highways, a big airport, pipelines, and residential areas), transforming the territorial structure. The rural territories considered not competitive were left out and projects of integration of "modern" agricultural production chains were the only impelled, leaving just $80 \%$ of regional agriculture (Bernal, 2005). 
The process of expropriation or selling of ejidos favored the urbanization and construction of larger infrastructures ${ }^{3}$, increased the migration to the city and changed the ejidatarios activities from farmer to laborer in the industrial area of Puebla. Some ejidatarios got a job in the construction industry, others preferred to acquire land in remote agricultural areas of the city "not to stop being peasants", as one leader of ejido in Puebla periphery said (Pérez-Avilés, 2005).

In the state of Morelos (south of Mexico City metropolitan zone), the polarization of its territory and of its neighboring regions, mainly in the Cuernavaca-Cuautla corridor, has reinforced the process of accelerated urbanization on the peripherial agricultural areas, with serious consequences to the local crops pattern and with an intense dispute over the use of hydric resources, originally for the agricultural irrigation and gradually transferred to the urban supply (Avila-Sánchez, 1997, 2006). Nevertheless, the existence of agricultural practices brought into the city and his periphery is recognized to attend the expectations of local population, for economical subsistence or as an established productive activity. In the same way, the developing of industrial areas has provoked important impacts in the culture and daily life of the traditional agrarian communities, as it was in the case of the creation of the Cuernavaca Valley Industrial City Project (Peimbert, 2003). The territorial changes expressed in the cities of the state of Morelos are a new expression of the subsidiary character that historically has been around the great national metropolis (Avila-Sánchez, 2001).

An ejidal leader in Chiconcuac (south of Cuernavaca), a sugarcane and rice producer, had to switch agricultural work with other activities (located in the industrial area of Jiutepec, other municipality in the metropolitan area of Cuernavaca). He pointed out that "while I was in the activity of producing sugarcane, I also worked 25 years in the Nissan auto assembly plant in Jiutepec (until 2005). When the plant cut its staff, I settled with the factory and use the compensation to purchase a set of taxi plate permits, which I rent to have an extra income. Now it is $60 \%$ of my income, the rest comes from agriculture. Some of my children cooperate with the family income but they are not interested in agriculture. One of them works at Unilever, a chemical company in the industrial zone of Cuernavaca (CIVAC). Another one works in a golf course in Cuernavaca and yet another daughter works in the real estate company GEO (they buy entire ejidos!!!). Other fellows' ejidatarios are in a similar situation, they do not live entirely from agriculture, they compliment the family economy with commercial initiatives, for example a little shop, a butcher shop or any other activity in Cuernavaca..." (Interview with an ejidatario that produces sugarcane in Chiconcuac, Cuernavaca. Ávila-Sánchez, 2004).

The Yautepec ejido, located in a highly-fertile valley in central Morelos, has almost 9000 hectares that hold important agricultural activity. There, more than $90 \%$ of irrigated land is still dedicated to agriculture and the remaining $8 \%$ is fractioned or sold. In the mountains or hills containing no water or irrigational systems, about $60 \%$ of the lands previously used as farms were sold to real estate companies for the construction of new housing. Buyers are primarily inhabitants of Mexico City (located within 100 kilometers from the town), who buy houses with communal swimming pools to occupy during the weekends. According to the ejidal leader, "Yautepec someday will be a colony or neighborhood of Mexico City..." (Interview with an ejidal leader of Yautepec. ÁvilaSánchez, 2004).

The Texcoco region (east of Mexico City), still is a huge zone of agricultural and cattle production. It has resisted the attack of the urbanizers, because of the poor quality of the waters used in the process of production (Navarro, 2000). The Texcoco region is a large urban-rural conglomerate of 25 municipalities with at least 400000 inhabitants, and it is part of the hierarchy of the metropolitan zone of Mexico City. Texcoco has experimented radical changes in the structure of the regional 'economically active population' between 1970 and 2000, as a result of intense urbaniza-

3. Since early 1970, about 3000 hectares have been expropriated in ejido areas in peripheral municipalities of the metropolitan area of Puebla, with the intention of building highways, waterworks, oil installations and power distribution (Pérez-Avilés, 2005). 
tion and changes in land use. The whole region decreased from 37\% of the economically active population engaged in primary activities, to only $7 \%$ in 2000 . In contrast, the percentage of the population engaged in tertiary activities increased from 24\% to 55\% between 1970 and 2000. The industrial activities grew from $25 \%$ to $34 \%$ over the same period of time. While the primary EAP has lost population in both relative and absolute numbers, the practice of agriculture continues, especially in periurban areas. The explanation seems to be related to their culture and identity, which has resulted in the preservation of their community ties ${ }^{4}$.

On the other hand, important processes happen in the Valley of Lerma-Toluca (west of Mexico metropolis), where the policies of industrial development and construction of transport infrastructure (mainly Toluca international airport), have changed the agricultural area and the ejidales properties in the zone. Nevertheless, it continues the periurban agriculture practices to satisfy the urban markets demands (Orozco, 2000, 2003).

The Toluca Metropolitan Zone (ZMT), the sixth greatest zone in Mexico, has experienced an impressive urban dynamics since 1960. Until 1980 its growth rate has been above 3\% higher than the national average, although nowadays it has decreased. In 2003, public ownership represented $65 \%$ of the municipalities of the metropolitan area (69 ejidos and 17 agrarian communities). Urban growth has taken place on lands where traditionally agricultural activities were performed. This situation had an impact on the occupational structure of adjacent rural areas to the metropolis. In 2000, the municipalities of Toluca and Metepec (metropolitan urban municipalities) had as tertiary occupation more than $60 \%$ of the EAP. In other originally rural municipalities, with rapid industrial transformation (Lerma and San Mateo Atenco), 50\% of the population is engaged in secondary activities. In most municipalities under the metropolitan influence, the occupational services are predominant. In the formation of periurban areas is evident the predominance of secondary and tertiary activities, which have gradually replaced agricultural activities (Orozco, 2006).

In the state of Hidalgo (north of Mexico City), the recent most important territorial transformations have happened in the cities of Pachuca and Tizayuca. Both cities developed quick processes of conurbation on lands of low agrological capacity, where numerous sets of individual houses were created. The city of Tizayuca, due to its expansion tendencies, develops important functions within the urban system that governs the metropolitan zone of Mexico City (Fabre, 2003). The nexus will be fortified with the restoration of the international airport terminal that has been projected in this area. The existence of urban and periurban agriculture as an alternative, is expressed due to the crisis of national agriculture. To produce for self-consumption or, to provide urban fresh vegetables to the market are still active.

\section{A reflection about rural periurban spaces in Central Mexico}

In less developed countries like Mexico, rural spaces have experienced an intense process of development in capitalist relations' production in agriculture. Peasants and ejidatarios have participated in this process, but an unequal situation as to the benefits and access to resources. At the present moment, the advance of urbanization is a threat for the inhabitants and actors of the rural spaces, mainly for the ones closer to the cities. The uncontrolled urban expansion will deepen the changes in the use of lands, in addition to important transformations in the productive structure of the peripheral localities in the cities. The urbanizing advance on territories of social property (ejidos) create incidence on the urban morphology and the structure of the rural space, in the use and management of natural resources, as in other aspects of the cultural scope. The establishment of policies of sustainable rural development could face the advancement of the accelerated

4. An ejidatario of Papalotla, Texcoco stated: "Corn planting is no longer good business, it is cheaper to buy imported corn than to produce it, besides I have increasingly less time. I come out late from my job at the factory and then travel from Mexico City [...] I keep planting a small area by tradition. I am the son of peasants; my parents taught me and I want to teach my children [...] everyone here plants even if just a little, whether or not is good business, that is another thing". (Interview with ejidal leader of Texcoco, Mexico, Ávila-Sánchez, 2005). 
urbanization that absorbs - at great speed - the surrounding agricultural surfaces. These public policies have top priority in local management and in the handling of the periurban territories.

A question of utmost importance in the analysis of periurban spaces relates to territorial transformations due to economic factors, especially those which are derived from structural adjustments in the economy (changes in the form of land tenancy, social policies and investments in urban and rural settings). It is also important to know their significance and effects on the local economy, like the changes in land use (from agricultural to urban or industrial uses and vice versa), the development of industrial, handcrafts and/or maquila activities, the practice of primary activities (agriculture, livestock farming, forestry, aquaculture) at the family level, or the gradual growth of the service sector, a phenomenon which has been widely developed in Mexico and in Latin America.

From the point of view of the construction of land identity by the periurban inhabitants, one must analyse the new roles and strategies that local actors adopt in urban-rural transition zones; the social-territorial networks which exist there; the new identities the periurban inhabitants build. Also, it would important to study the social imaginary, the feeling of territorial belonging and the link between symbolism and territoriality regarding cultural patrimony.

Territorial changes occuring in the central region of Mexico are rapidly expressed in the peripheral areas of large cities in Mexico. It is also evident in the changes inside the productive sectors, from primary to industrial and tertiary, while strengthening the character of mixed economies and urban-rural labor structure, which becomes more heterogeneous, with urban-rural characteristics. The decentralization of city functions that are relocated in medium and small towns, in turn incorporate the rural or urban-rural peripherial zones, linked to the influence of major urban centers, in this case the Metropolitan Zone of Mexico City. This process of urban sprawl creates a segregated housing market, where there are big disparities between housing for the working class and those that were built for the middle class members recently moved to the periphery (newrurals).

A fundamental issue in the periurban areas of the central region of Mexico remains the environmental matter; the deterioration of nature is linked to cities, and urbanization contribute significantly through the consumption of resources, land use changes and waste production, in addition to the visual impact caused by the construction of large infrastructures and housing projects. The dispute over water resources is also an issue of great importance for the dynamics of cities in Central Mexico, and the more frequent disputes of water for agricultural uses caused by the creation of new urban spaces in the periphery of cities. Simultaneously, the formation of periurban belts brings the deterioration of local territories and the transformation of its social tissue.

In conclusion, the different manifestations witnessed in periurban spaces constitute an important area of study, as this is a phenomenon which we will see for some time to come under new forms and types of global economy.

\section{References}

Aguilar, A. G. (coord.), 2006 Las grandes aglomeraciones y su periferia regional. Experiencias en Latinoamérica y España. México, Instituto de Geografía-UNAM/Conacyt/M.A. Porrúa editores. p. 377.

Aguilar A., Escalona M., 2000. Expansión metropolitana de la Ciudad de México y el ámbito rural de Texcoco, in Torres-Lima P. (comp.), Procesos metropolitanos y agricultura urbana, México, UAM/Xochimilco - FAO, p. 87-101.

Avila-Sánchez H., 1997. Agricultura, urbanización y cambios territoriales en el estado de Morelos, Geografía y Desarrollo, n 14, México, Colegio Mexicano de Geógrafos, A.C. p. 53-58.

Avila-SÁnchez H., 2001. Ideas y planteamientos teóricos sobre los territorios periurbanos. Las relaciones campo-ciudad en algunos países de Europa y América, Investigaciones Geográficas. Boletín del Instituto de Geografía, México, IG-UNAM, nº 45, p. 108-127. 
Avila-Sánchez H., 2006. La agricultura urbana y periurbana en el Estado de Morelos, Cuernavaca, mecanografiado, p. 289.

Benko G., Lipietz A. (coord.), 1994. Las regiones que ganan. Distritos y redes. Los nuevos paradigmas de la Geografía Económica, Valencia, Ediciones Alfonso el Magnánimo, p. 401.

Benko G., Lipietz A., (coord.). 2000 La richesse des régions. La nouvelle géographie socio-économique, París, PUF, coll. «Économie en Liberté », p. 564.

Bernal H., 2005. La cuarta zona metropolitana Puebla-Tlaxcala: su desarrollo, sus contradicciones y posicionamiento en dos cortes históricos, in Ávila-Sánchez H., Silva S., Pérez R., Lo urbano desde lo rural. El caso de la zona conurbada de la cindad de Puebla, Puebla, Benemérita Universidad Autónoma de Puebla, col. «DUDESU-ICUAP », n 1, p. 37-55.

Canabal B., (coord.) 2000. Agricultura urbana en México, Red Mexicana Aguila de Agricultura UrbanaUAM-X. p. 119.

Delgado J., 2003. Transición rural-urbana y oposición campo-ciudad, in Agullar A. (coord.), Urbanización, cambio tecnológico y costo social. El caso de la región centro de México, IG-UNAM, CONACYT, Miguel Angel Porrúa Editores, p. 73-118.

Delgado J., 1999. La nueva ruralidad en México, Investigaciones Geográficas. Boletín del Instituto de Geografía, n³ 39, México, IG-UNAM, p. 82-93.

Delgado J., Larralde A., Anzaldo C., 1999. La Corona Regional de la Ciudad de México. Primer anillo exterior en formación, in Delgado J., Ramïrez B. (coord.) Las transiciones de la Ciudad de México. Escenarios de una nueva formación territorial, México, Universidad Autónoma Metropolitana-Plaza y Valdés editores, p. 333.

Di Meo G., 1998. Le territoire un concept essentiel de la géographie social, in Hérin R., Muller C. (eds.), Espaces et Sociétés à la fin du XXe siècle. Quelles géographies sociales?, université de Caen, Maison de la Recherche en Sciences Humaines n 7, p. 49-62.

Fabre D., 2003. Ordenamiento Ecológico Territorial de la región Valle Pachuca-Tizayuca, Pachuca, Universidad Autónoma del Estado de Hidalgo; Consejo Estatal de Ecología-Hidalgo. s/p.

INEGI (2006). II Conteo de Población y Vivienda 2005, México, Instituto Nacional de Estadística, Geografía e Informática, s/p.

Krugman P., 1996. Geography and Trade, Cambridge/Leuven, The MIT Press/Leuven University Press, p. 144.

Navarro H., 2000. Transformaciones territoriales y la agricultura periurbana en el este del Valle de México, in Canabal B. (coord.) Agricultura Urbana en México, México, Red Aguila Mexicana de Agricultura Urbana, UAM-X, p. 92-109.

Orozco E., 2000. Sistema agrario ejidal en el contexto de la globalización: el caso de la Cuenca Alta del Río Lerma, México (planteamiento metodológico), in Memoria de Sexto coloquio de investigación, Toluca, Universidad Autónoma del Estado de México, s/p.

Orozco E., 2003. Nueva Ruralidad en la Cuenca Alta del Río Lerma México in Memorias del IX Encuentro de Geógrafos de América Latina, Mérida, Yucatán. Versión CD, s/p.

Orozco E. 2006. Escenarios interpretativos. Tendencias en la transformación de espacios rurales y periféricos de la Zona Metropolitana de la Ciudad de Toluca in Investigaciones Geográficas, Boletín del Instituto de Geografía, UNAM, nº 60, 2006, p. 110-126.

Peimbert G., 2003. Cambio cultural e identidad local en zonas urbano-rurales de la Zona metropolitana de Cuernavaca, Morelos, Documento mecanografiado, p. 85.

PÉREz-Avilés R. 2005. Las transformaciones de la estructura agraria ejidal en la zona conurbada de la ciudad de Puebla (1980-2004), in Ávila-Sánchez H., Silva S., Pérez R., Lo urbano desde lo rural. El caso de la zona conurbada de la ciudad de Puebla, Puebla, Benemérita Universidad Autónoma de Puebla, col. «DUDESU-ICUAP », nº 1, p. 59-111.

Pérez-Avilés R., Silva-Gómez S. E., 2003. Integración urbanismo y agrosistemas rurales: el caso de la zona conurbada a Puebla-Tlaxcala, Cuarto Congreso Nacional de la Asociación Mexicana de Estudios Rurales, Morelia, Michoacán, Versión CD, s/p. 
Piolle X., 1998. Le territoire, ou des dimensiones spatiales des rapports sociaux, in Herin R., Muller, C. (eds.) Espaces et Sociétés à la fin du XXe siècle. Quelles géographies sociales?, Université de Caen, Maison de la Recherche en Sciences Humaines, n 7 , p. 75-86.

Ramírez B., 2000. Las dimensiones regionales de la relación campo ciudad. El caso de Querétaro, México, in Torres-Lima P. A. (comp.), 2000. Procesos metropolitanos y agricultura urbana, México, UAM Xochimilco/FAO, p. 67-85.

Torres-Lima P. A. (comp.), 2000. Procesos metropolitanos y agricultura urbana, México, UAM Xochimilco/ FAO, p. 253.

\section{Interviews}

Ávila-SÁnchez, H., 2004. Interview with ejidal leader of Yautepec, July 15, 2004.

Ávila-SÁnchez, H., 2004. Interview with ejidatario sugarcane producer of Chiconcuac, Cuernavaca), August 24, 2004.

Ávila-Sánchez, H., 2004. Interview with ejidal leader of Jiutepec, April 10, 2005.

Ávila-SÁnchez, H., 2005. Interview with ejidal leader of Texcoco, Mexico, February 13, 2004.

Pérez-Avilés, R. 2003. Interview with ejidal leader of ejido San Juan Tlautla, Puebla, n/d.

Cet article a été reçu le 9 février 2011 et définitivement accepté le 2 novembre 2011. 